\title{
Greening the Danes? Experience with consumption and environment policies
}

Christensen, Toke Haunstrup; Godskesen, Mirjam Irene; Gram-Hanssen, Kirsten; Quitzau, Maj-Britt; Røpke, Inge

Published in:

Journal of Consumer Policy

Link to article, DOI:

10.1007/s10603-007-9029-2

Publication date:

2007

Link back to DTU Orbit

Citation (APA):

Christensen, T. H., Godskesen, M. I., Gram-Hanssen, K., Quitzau, M-B., \& Røpke, I. (2007). Greening the Danes? Experience with consumption and environment policies. Journal of Consumer Policy, 30(2), 91-116. https://doi.org/10.1007/s10603-007-9029-2

\section{General rights}

Copyright and moral rights for the publications made accessible in the public portal are retained by the authors and/or other copyright owners and it is a condition of accessing publications that users recognise and abide by the legal requirements associated with these rights.

- Users may download and print one copy of any publication from the public portal for the purpose of private study or research.

- You may not further distribute the material or use it for any profit-making activity or commercial gain

- You may freely distribute the URL identifying the publication in the public portal

If you believe that this document breaches copyright please contact us providing details, and we will remove access to the work immediately and investigate your claim 
Published in Journal of Consumer Policy (2007) 30:91-116. The original publication is available at www.springerlink.com.

URL: http://www.springerlink.com/content/n5m875h2884686h2/

DOI: $10.1007 /$ s10603-007-9029-2

\section{Greening the Danes? Experience With Consumption and Environment Policies}

Toke Haunstrup Christensen, Mirjam Godskesen, Kirsten Gram-Hanssen, Maj-Britt Quitzau and Inge Røpke

\section{Author notes:}

T.H. Christensen

Department of Manufacturing Engineering and Management, Technical University of Denmark, Produktionstorvet, Building 424, 2800 Kgs. Lyngby, Denmark

e-mail: thc@ipl.dtu.dk

M. Godskesen

Department of Manufacturing Engineering and Management, Technical University of Denmark, Produktionstorvet, Building 424, 2800 Kgs. Lyngby, Denmark

e-mail: $\underline{\text { mg@ipl.dtu.dk }}$

K. Gram-Hanssen

Danish Building Research Institute,

Dr. Neergaards Vej 15, 2970 Hørsholm, Denmark

e-mail: kgh@sbi.dk

M.-B. Quitzau

Department of Policy Analysis, National Environmental Research Institute

P.O. Box 358, Frederiksborgvej 399, 4000 Roskilde, Denmark

e-mail: $\underline{\text { mbq@dmu.dk }}$

I. Røpke

Department of Manufacturing Engineering and Management, Technical University of Denmark, Produktionstorvet, Building 424, 2800 Kgs. Lyngby, Denmark

e-mail: ir@ipl.dtu.dk

Keywords: consumer-oriented environmental policy, sustainable consumption, housing, transport, information and communication technology, Denmark 


\title{
Greening the Danes? Experience With Consumption and Environment Policies
}

\begin{abstract}
Consumer-oriented environmental policies came high on the political agenda during the 1990s. Internationally, consumers were assigned a key role in environmental policies; also in Denmark, political initiatives were taken to promote sustainable consumer behaviour. In this article, the results of Danish policies related to consumption and environment are assessed by considering first, the environmental impacts of the political measures, and second, whether the policies have succeeded in addressing the dynamics behind increasing consumption. The study combines a theoretical understanding of consumption as an inseparable part of daily practices with empirical analyses of three fields of consumption: Housing, transportation, and information and communication technology. It is pointed out that policies to promote sustainable consumption are successful only when technological development, economic structures, and information are all in accordance with each other, and this is only the case when sustainable consumption does not conflict with economic growth. A more fundamental critique thus concerns the failure of Danish consumer-oriented environmental policies to address consumption growth and the rising standards for "normal consumption".
\end{abstract}

During the 1990s consumers and citizens were increasingly assigned the task of contributing to more sustainable development. The involvement of consumers in environmental issues was part of a general trend in most industrialized countries, where environmental policies were broadened in scope and included a wider range of instruments and responsible actors. In Denmark, consumeroriented environmental policies have been on the political agenda since the beginning of the 1990s, but precursors can be traced back even longer. Denmark was among the forerunners with regard to initiating measures to regulate consumer behaviour relating to energy consumption in the 1970s when energy savings were mostly motivated by economic and supply problems - and in the 1990s with regard to the formulation of modernized environmental policies, including consumer-oriented measures (Andersen, M. S., 1997; IEA, 2006; Remmen, 2006). Experience has thus been gathered 
for several years now, so it is appropriate to make an appraisal of the attempts to promote more sustainable consumption and to assign a share of the environmental responsibility to consumers. As one of the frontrunners, Denmark provides an interesting case for discussing the achieved results and experiences even though policies and consumption patterns are always context dependent, and Danish experiences are not directly transferable to other countries.

In the following, we use the terms consumer-oriented environmental policies and sustainable consumption policies synonymously. We must thus emphasize that we are only dealing with environmental aspects of sustainability in this article. Consumer-oriented environmental policies are not usually called sustainable consumption policies in Danish, but we sometimes use the term here, because it is widely used in the literature (Cohen, 2005; Fuchs \& Lorek, 2005).

In this article, we intend to assess the results of Danish consumer-oriented environmental policies and to discuss what can be learned from the experience. The assessment of the results is based on two different perspectives. First, we consider whether the political measures have had a positive impact on the environmental situation: What are the environmental successes and failures? Second, we discuss the importance of the results in relation to the dynamics that simultaneously tend to more than outweigh the achievements: To what degree have the policies effectively addressed the driving forces behind environmentally problematic consumption growth? Regarding the learning that can be based on the experience, we intend to pinpoint the conditions and factors that are decisive for the impact of measures in different fields of consumption. Although we discuss a variety of measures, it should be emphasized that we do not focus on the effect of each specific instrument in isolation (e.g., whether taxes are better than information or how taxes should be designed), but try to assess the combined effect of sustainable consumption measures in different fields of consumption. We intend to assess the historical achievements of the policies in a broader perspective in order to contribute to a more general discussion on the impact, relevance, and effectiveness of consumer-oriented environmental policies. Our perspective has thus much in common with that of Fuchs and Lorek, who study the development of global sustainable consumption governance at the level of international governmental organizations (Fuchs \& Lorek, 2005), whereas we provide a country case study. 
The questions are discussed on the basis of three fields of consumption - housing, transport, and ICT (information and communication technologies). Together these fields include both successes and failures of sustainable consumption policies, and they differ from each other in several ways that can illustrate the different conditions for implementing such policies. It would have been obvious to also include the field of food that has heavy environmental impact and comprises early examples of consumer-oriented measures. Due to space concerns, we have had to restrict ourselves, so we have chosen to refer only briefly to this field because much has already been written on Danish experiences with regard to food consumption in an environmental perspective (Beckmann et al., 2001; Grunert, 1993; Grunert \& Juhl, 1995; Halkier, 1999).

The three fields have also been chosen because they carry great weight in private consumption and are responsible for a sizeable part of resource appropriation and pollution. For example, housing (heating and electricity) and road transportation (including transport of goods) represented 29\% and 25\%, respectively, of the total Danish end-use of energy in 2004 (Danish Energy Authority, 2005). Although energy consumption in relation to ICT is not comparable to housing and transport, it is growing in these years due to increasing numbers of ICT products in households. A recent study shows that television sets, video recorders, hi-fi, and IT (including both use and standby) represent approximately $15-20 \%$ of the electricity consumption in Danish households (Gram-Hanssen, 2004; Gram-Hanssen, 2005). Furthermore, local environmental problems in relation to the extraction of metals and the management of compound electronic waste make this a relevant case (DEPA, 2003).

The next section provides some background information on the history of sustainable consumption policies, and Danish consumer-oriented environmental policies are described in an international context. The third section outlines our theoretical perspective and stresses the importance of understanding everyday consumption practices as embedded in material, social, and symbolic relations. The theoretical perspective directs our analysis of the three fields of consumption - housing, transport, and ICT - in the section on the development in consumption. The analysis focuses on the development in consumption since the early 1980s and the sustainable consumption initiatives, including the successes and failures of these initiatives. Furthermore, changes in the practices of everyday life are discussed in order to identify possible dynamics behind further growth within the three fields of consumption. The section "Evaluating the impact of 
consumer-oriented environmental policies" summarizes the main findings from our case studies and includes a discussion of the general characteristics of the successes and failures of consumeroriented environmental policies and the problem of continued growth. Finally, the article concludes with an assessment of the results of the Danish consumer-oriented environmental policies and what can be learned from the Danish case.

\section{The Development of Consumer-oriented Environmental Policies}

Consumer-oriented environmental policies emerged and developed in relation to the more general trends in the public and political interest in environmental issues. These trends have to a large extent been parallel in most countries in Western Europe and North America, but national characteristics also play a role (Jamison, 2001; Jamison et al., 1990). In this section, we outline very briefly the emergence of sustainable consumption policies in the Danish historical context.

The environmental agenda emerged in the 1960s, and in the beginning of the 1970s, Denmark and most other industrial countries established institutional structures and environmental legislation (Weale, 1992). Already in this early phase, Danish grass-roots organizations tried to make consumers aware of the environmental impacts of their consumption and to draw attention to the wastefulness of consumer society (Olsen et al., 1980, pp. 53-66), but the consumption issue was not placed on the political agenda. In the mid-1970s, however, the energy crisis gave great impetus to interest in the role of consumers in relation to energy consumption. Since the energy crisis was understood as a crisis of supply and high energy prices, the first political attempts to encourage energy savings had little to do with environmental aspects. But these attempts comprised the start of assigning a role to consumers with regard to daily behaviour, investments, and the purchase of goods. The instruments used comprised campaigns, direct regulation, and subsidy schemes that have been expanded and developed over time. Later, when acidification and (even later) the greenhouse effect appeared high on the agenda, the same policies were redefined as consumeroriented aspects of environmental policies.

While much attention was being devoted to the energy issue, implementation of environmental legislation from the 1970s was progressing very slowly (Andersen, 1989; this was the case in other countries as well, Weale, 1992). In the middle of the 1980s, environmental organizations and increased media interest called for politicians to address the implementation deficit, and 
environmental issues re-appeared forcefully on the political agenda (Andersen, M. S., 1997). Simultaneously, non-point sources of pollution came more into focus, and the awareness of global environmental problems increased. During this period, broader political interest in consumption and environment emerged, and the concept of the political consumer became popular. Political consumption had a longer history, but in this period the concept had a real breakthrough and became closely related to environmental issues (Lassen, 2002). One of the first areas for environmentally oriented political consumption was food. In the wake of the social movements of the 1970s, groups of people had moved to the countryside to grow organic food and to experiment with new ways of life. These experiments developed into production units that were able to supply the emerging market for organic food products. In 1987, the organic producers succeeded in pressing the Danish government to establish a labelling scheme for organic food products.

However, consumer-oriented environmental policies did not really come into being until the 1990s. The breakthrough came in relation to the surge of environmental interest in the wake of the Brundtland report in 1987 and the Rio conference in 1992. The policy statements from the Rio conference emphasized the need for aiming at both sustainable production and consumption, and the slogan "think globally, act locally" was popularized, encouraging the involvement of a broader range of actors in achieving more sustainable development. Following the launch of Agenda 21 at the Rio conference, several local activities were initiated in Denmark, including experiments with so-called green municipalities. Government funding of local projects was provided with the establishment of The Green Foundation in the middle of the 1990s. Through this foundation, several green centres and local "green guides" were supported throughout the country. Among many other activities, these institutions dealt with consumer-related issues such as advice concerning the choice of green products and green investments in, for instance, solar panels and compost bins (Gram-Hanssen, 1998; Læssøe, 2001).

Simultaneously, changes took place in the established environmental regulation of production, as prevention was increasingly emphasized instead of cleansing, and the traditional focus on production processes was widened to include the whole lifecycle of products (DEPA, 1999; Jørgensen, 2005; Remmen, 2002). As a consequence, consumers became relevant actors, as they were assigned the role of demanding the more environmentally friendly products that producers should be encouraged to provide. The development of consumer-oriented environmental policies 
thus formed part of the process that has been characterized as ecological modernization or the new politics of pollution (Mol \& Spaargaren, 2000; Weale, 1992). The basic idea was that environmental improvements could be reconciled with economic growth, and that a positive spiral could be initiated by the interplay between consumer interests and progressive firms, supported by policy instruments such as economic incentives, voluntary agreements, labelling, public procurement, and promotion of environmental management systems. In Denmark, these instruments were included in the revision of the Environment Act in 1992, a revision that also emphasized the aim of prevention and the development of cleaner technologies. In addition to the labelling of organic produce, other labelling schemes were implemented in the 1990s such as the European ecolabel The Flower and the Nordic Swan. Compulsory energy labelling of electric appliances such as refrigerators and freezers was introduced in the EU in 1995 (the so-called energy arrows from A to G). In 1996, Denmark introduced energy labelling for all privately owned dwellings: When the dwellings are traded they have to undergo an energy test that includes recommendations for improvements of the building. Furthermore, consumers were targeted in relation to areas such as water savings (see later) and waste handling, as plans for recycling and waste reduction took shape during the 1990s.

While the mid-1990s was a period with much focus on environmental issues and much policy innovation related to integrated product policy (Remmen, 2006), the first signs of a backlash became visible in the late 1990s, when the political focus shifted towards other issues, primarily immigration. This issue was decisive for the change of government in 2001, when a liberal government succeeded a coalition government led by the Social Democrats. The environment had not been featured in the election campaign, but the new government immediately cut back spending for research and development programmes, subsidy schemes, and support for organizations in the environmental field - concurrent with the establishment of the Environmental Assessment Institute led by the controversial Bjørn Lomborg. Important parts of the integrated product policy were dismantled (Remmen, 2006), and sustainable consumption policies entered a period of relative stagnation. The reduced focus on consumers as a target group for environmental policy can also be seen in other countries, such as the Netherlands, which has been another frontrunner with regard to sustainable consumption policies (Martens \& Spaargaren, 2005). 
In August 2004, the Minister for Environment was replaced by a more environmentally ambitious politician, and some liberals started to argue that it is time to stop the cuts and re-introduce, for instance, subsidies for renewable energy. Consumer responsibility reappeared on the agenda, but the new initiatives were few and mainly symbolic, such as the information campaign called "Green responsibility - make a difference" launched by the Danish Ministry of Environment in 2005. The campaign encourages people to include environmental concerns in their daily behaviour by providing information and advice about environmentally beneficial behaviour on a website (http://www.groentansvar.dk).

As described above, consumer-oriented environmental policies emerged from and were a part of environmental policies. However, it is worth noting that sustainable consumption, with some delay, also became an aspect of consumer policy: As environmental policy developed consumer-oriented aspects, consumer policy developed environmentally oriented aspects. Traditionally, consumer policy has focused on the defence of consumer interests in the market, and of course, this is also relevant in relation to environmental issues (e.g., protection of consumers against dangerous products, toxic substances). But during the 1990s, sustainable consumption also emerged as a relevant concern for consumer policy, implying that consumer policy is also about the responsibility of consumers (Mathios \& Mayer, 2005; Reisch, 2004).

\section{Theoretical Perspectives}

Before analysing the impact of sustainable consumption policies in different fields, we introduce the theoretical perspectives that inspire our assessment. In particular, we draw on insights regarding the embeddedness of consumption in a broader socio-economic framework.

Consumer behaviour literature, which has grown considerably parallel with the development of sustainable consumption policies, focuses mainly on the relationships between consumers' values, attitudes and motives in relation to the environment and their actual behaviour. Although this tradition is based primarily on a psychological perspective, the perspective also includes considerations regarding the possibilities and limitations facing consumers when they try to act in accordance with their values and attitudes (Gatersleben, \& Vlek, 1998; Ölander \& Thøgersen, 1995). For instance, the Needs-Opportunity-Ability model emphasizes that individual behaviour "is embedded in a societal context by the addition of five general macro-level factors, which inevitably 
influence the individual behaviour concepts" (Gatersleben \& Vlek, 1998, p. 145). These factors include technology, economy, demography, institutions, and culture (the model is applied in OECD, 2002). A recent paper by Thøgersen (Thøgersen, 2005) also emphasizes how external conditions, such as cultural meanings and norms as well as infrastructure, can constrain sustainable lifestyle changes.

Within the marketing literature, the importance of macro level conditions is particularly emphasized in the studies of the "dominant social paradigm" (DSP). In a survey of research on marketing and environment, Kilbourne and Beckmann (1998) argue that macro aspects had a low priority until the mid-1990s, when the focus was expanded to include more general ecological beliefs, environmental values, and paradigms. The core concept used in the macro-oriented studies, the DSP, refers to the overall cultural context that serves as an underlying structure motivating environmental concern and action at the individual level. The DSP consists of basic cosmological beliefs as well as socio-economic beliefs about the interplay between politics, economy, and technology; for instance, the DSP includes technological optimism, focus on private property, atomized individualism, and a belief in free markets (Kilbourne et al., 2002). The proponents of the DSP-approach argue that it is decisive to examine such basic beliefs in order to understand consumer behaviour and develop successful policy strategies for a change toward sustainable development (Beckmann, 1998).

The conditions and dynamic forces that might more than outweigh the results of sustainable consumption measures receive an elaborate treatment in the sociological and socio-economic literature on consumption and environment (review in Røpke, 1999). Based on this literature, we emphasize here three driving forces behind ever increasing consumption aspirations - three drivers that constantly reappear in empirical studies and are present - although to varying degree - in most consumption fields. Of course, these drivers can only lead to increased consumption if they co-exist with economic growth and increasing disposable incomes, just as their effect can be enhanced by institutions such as consumer credit (elaborated in Røpke, 1999). First of all, rapid product innovation implies that consumers always have an impressive array of possibilities for renewed identity formation, better performance of various activities and daydreaming (Campbell, 1994) experienced by some as opportunities for playful pleasure and by others as demanding pressure (in the literature on environmental issues, technological change is mostly considered as part of the 
solution because of the potential for efficiency increases and cleaner production; from the perspective of consumption, however, technological change is an important driver behind increasing consumption and thus often behind increased appropriation of resources, see (Røpke, 2003; Røpke, 2001b). Secondly, the long-term trend towards individualization, especially in the form of the emancipation from traditional social categories such as "the family" or "the class" (Beck, 1992), is a strong force behind the demand for material goods that provide greater individual freedom of action. This is reflected both in the long-term trend towards smaller households and in the increase, for instance, in the number of televisions, personal computers and cars in each household (Røpke, 1999). Thirdly, the spreading of stress and time pressure is presently much debated in the public sphere as well as in the social sciences (Hochschild, 1997). In Denmark, average working hours tend to increase (Bonke, 2002), and many people experience an intensification of working life; a 2006-survey shows that about $60 \%$ of Danish employees feels stress on a monthly basis, while $15 \%$ reports that they are absent due to work-induced stress (Kudahl, 2006). Also in relation to leisure, 'the pace of life' seems to be increasing (Andersen, J., 1997; Rosa, 2003), calling for labour saving and time shifting devices (Southerton, 2003; see also Kring, 2005, for a recent study on the time-balance of work and family life, and the time-experience of modern people).

These and other consumption drivers can more than outweigh the results of sustainable consumption measures. Furthermore, the drivers are also active in fields that have escaped political attention and can aggravate environmental problems, so to say, behind the scene. Usually, only some selected areas of consumption and consumer behaviour are thematized in an environmental perspective, whereas extensive parts of environmentally problematic consumption are neglected. Consumers thus tend to interpret their behaviour as environmentally friendly when they perform a series of actions that symbolize environmentally correct behaviour, although they concurrently increase their environmental impact through rising consumption in other areas. Instead of assessing their overall behaviour in an environmental perspective, consumers consider only a small subset (a 'compartment') of actions environmentally relevant such as, for instance, recycling, buying organic vegetables, and using energy-saving bulbs. This is called 'compartmentalization' (Bartiaux, 2006; Iversen, 1996), and sustainable consumption measures sometimes tend to reinforce the phenomenon when they point out specific areas for environmentally friendly behaviour instead of placing overall consumption on the agenda. 'Compartmentalization' does not contradict the phenomenon of 
spillover effects where consumers involved in one form of environmentally correct behaviour are more likely also to take up other forms as well (Thøgersen \& Ölander, 2003), as the various actions considered in studies of spillover effects all belong to the 'compartment' of environmentally correct behaviour.

Recent sociological research has paid attention to consumption fields that neither have significant symbolic value in relation to environmentally correct behaviour, nor have been central to most consumption sociology, which has been preoccupied with cultural visibility and identity formation. This research focuses on ordinary and routine consumption and on the imperceptible development of "normal" consumption (Gronow \& Warde, 2001; Shove, 2003a; Southerton et al., 2004). For instance, Shove has highlighted the development of bathing and showering routines, the use of airconditioning, and practices in relation to laundry in an environmental perspective (Shove, 2003a; Shove, 2003b). Even if some of these fields of ordinary consumption receive environmental attention, the attention is predominantly limited to certain aspects. For instance, national campaigns in Denmark have recommended people to wash at lower temperatures (but not to reduce the amount of laundry) and to have showers instead of baths (but not to reduce the frequency of showers). The examples illustrate that campaigns usually deal with "efficiency" - the achievement of cleanliness in less environmentally costly ways - but not with "quantity" or "standard" - whether we really have to be so clean.

The research on ordinary consumption suggests that consumption must be understood from the perspective of social practices: Products and services are appropriated and used as integral parts of social practices (Warde, 2005). For example, food, refrigerators, and electric cookers are bought as parts of the practice of preparing meals, just as the washing machine, washing powder, and clothesline are appropriated as parts of the practice of washing clothes. Understanding consumption is thus about understanding social practices and the dynamics shaping these practices.

The everyday life of an individual is composed of a combination of practices, co-ordinated in time and space, to which the individual ascribes meaning at a symbolic level. Because many people share practical conditions and draw upon the same repertoire of societal ideas when they ascribe symbolic meanings to their activities, a series of practices will be common for larger groups - in some cases whole societies; in others, specific age groups or social groups. The shaping of practices 
that are shared by larger groups has great importance in relation to the size and composition of the overall consumption in society and thereby also for the environmental impacts of everyday life.

Thus, practices can be seen as embedded in material (technological systems, infrastructure, and objects), social (socio-economic institutions and social relations), and symbolic-meaningful (ideas and understandings) relations, which human actors - through the performance of practices - try to integrate. By doing this, human actors contribute to recreate and transform the conditions of their lives. The three aspects of social practices - the material, the social, and the symbolic meanings develop through interaction, co-evolution, implying that changes in one area can lead to changes in other areas as well. As such changes appear continuously - through technological changes, new understandings, and changing social institutions - social practices develop over time. As we demonstrate in the following sections, it is important to focus on the changing social practices and the imperceptible development of "normality", if we want to face the challenge of achieving sustainable consumption patterns.

\section{Development of Consumption}

In this section, the development of consumption during the last 20 years within our three cases (housing, transport, and ICT) is examined briefly, and sustainable consumption policy initiatives are described, including an overview of successes and failures. Finally, a short description of how consumption practices have changed is presented.

The three cases differ from each other in various ways: The housing case represents an area where the environmental impact has been reduced in certain respects, while the impact from transport is still increasing. Secondly, they deal with technologies in different phases of their development. For example, a refrigerator is a stabilized technology, where the environmental impact has been studied and minimized for several years now, while the future development of ICT is still open and unpredictable. This leaves a big potential for integrating environmental concerns in the design of ICT products and in the development of the ICT infrastructure. Thirdly, the cases are characterized by different dominating dynamics of consumption growth, as shown in the following analysis. 


\section{Case 1: Housing}

Environmental impacts from housing include energy and water consumption, use of construction materials, production of waste, and the appropriation of land area. In the following case description, however, we concentrate on energy and water consumption, as these areas have been the main focus for policies within the housing sector, and because they are the most well documented areas. Consumer-oriented policies concerning energy and water consumption have focused on the energy and water efficiency of buildings as well as on the continuous consumption resulting from people's daily habits. These policies have resulted in a notable increase in energy and water efficiency; however, the efficiency gains, especially for energy, have to some extent been outweighed by rising standards for housing comfort, size, and equipment, which have not been targeted by any policy measures.

\section{Development of consumption during the last 20 years}

A tendency toward growing energy consumption throughout the 1970s was markedly interrupted at the beginning of the 1980s. Since then, consumption of energy (both electricity and heat) has been more or less unchanged for the last 20 years (see figure 1). Households' water consumption decreased markedly by approximately one-third from 1989 to 2003 (see figure 2). This development in energy and water consumption has taken place simultaneously with considerable economic growth. In the 1970s, it would have been unthinkable to have economic growth and stable energy consumption at the same time, so in this sense these developments must be seen as an environmental success story.

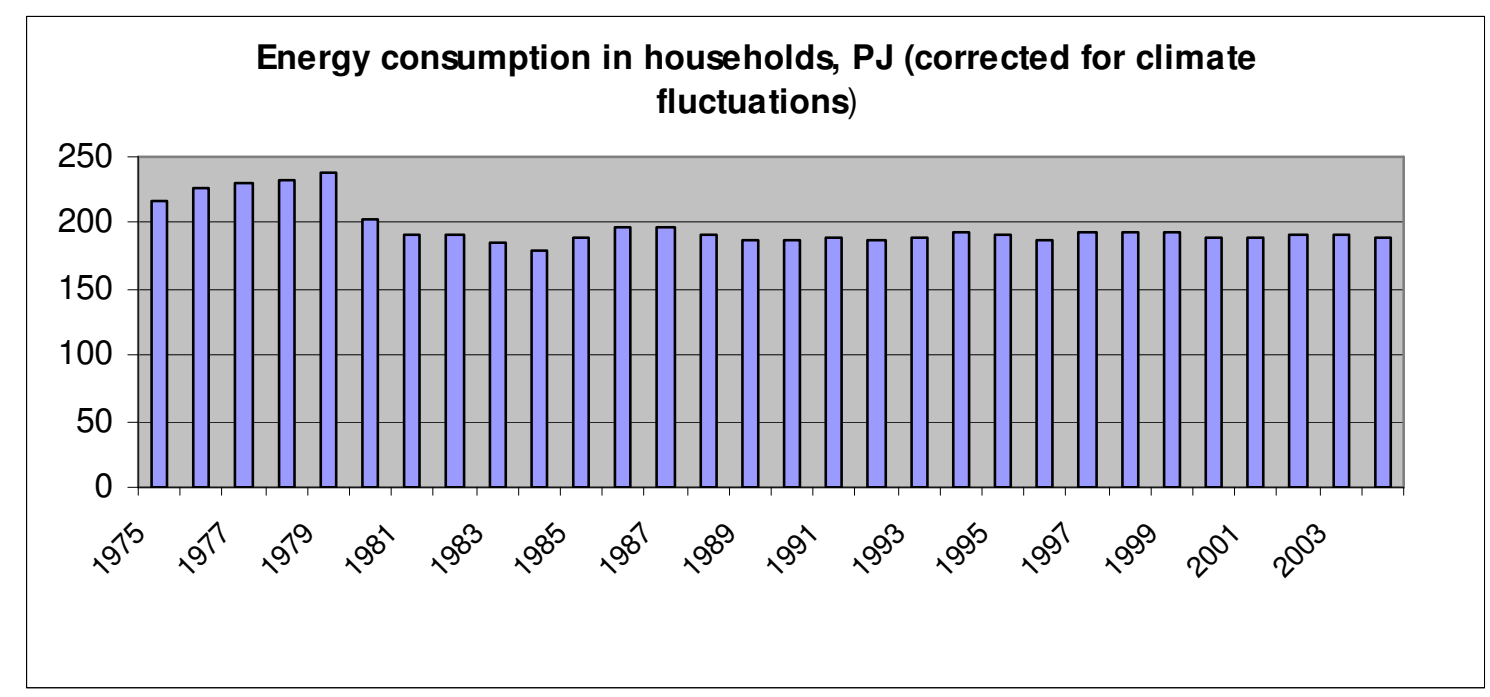


Figure 1: Final energy consumption (including both heat and electricity) in households corrected for climate fluctuations (Danish Energy Authority, 2005).

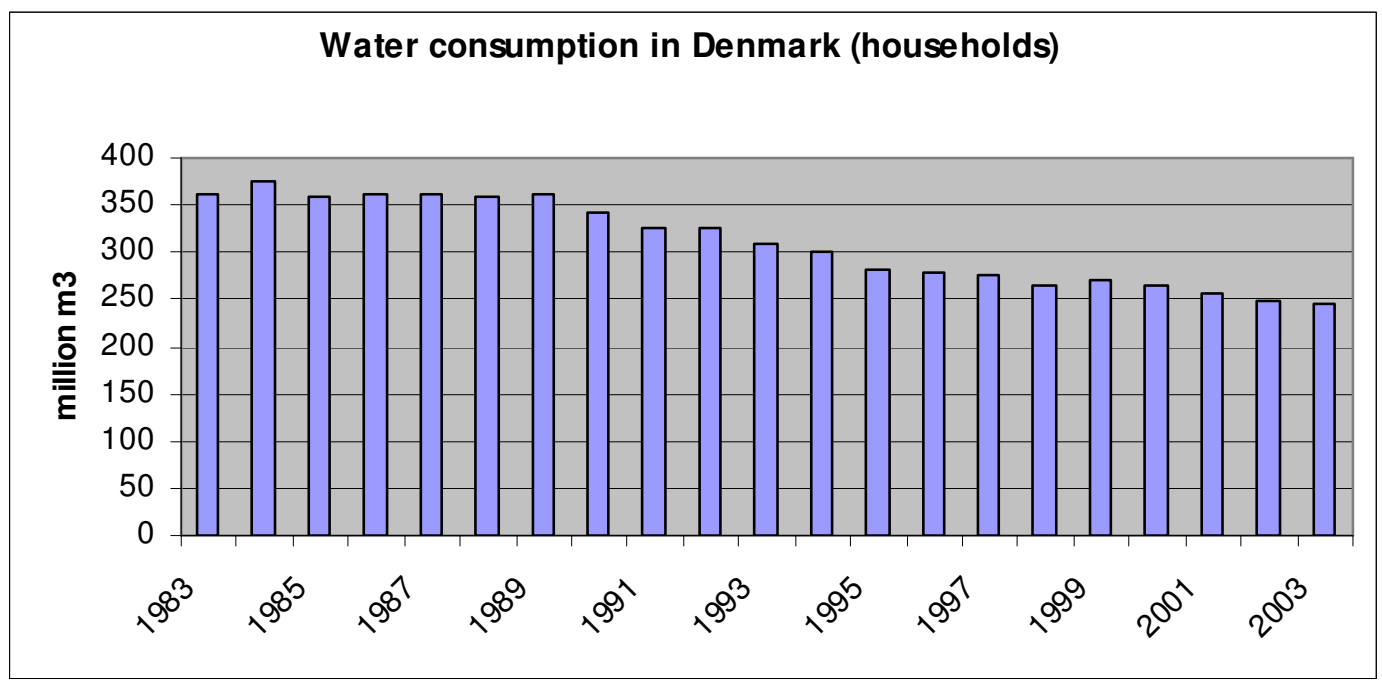

Figure 2: Development in water consumption in households (StatBank Denmark, 2005).

\section{Sustainable consumption policy initiatives}

This rather positive development in energy and water consumption is the outcome of an extensive list of policy initiatives. In relation to water consumption in households, a broad array of initiatives has resulted in the remarkable decrease. The idea that ground water is a limited resource that must be preserved has penetrated the consciousness of Danes as a result of water-saving campaigns in the 1980s and 1990s. Consequently, many people were willing to change their practices (research indicates that water consumption to a higher degree than energy consumption is influenced by attitudes (Gram-Hanssen, 2003)). Concurrently, technological development in relation to watersaving fittings, such as double-flush toilets and water-saving showerheads, has been supported by the drastic increase in water taxes of $300 \%$ (Hoffmann et al., 2005). Also, initiatives have been made to make water consumption more visible in daily life. In blocks of flats, water metering has been installed in each dwelling and historical data on water consumption is illustrated on water bills. There are still many blocks of flats without individual metering, but the installation of 
metering is obligatory in cases of renewal of water supply systems (Bygge- og Boligstyrelsen, 1997).

In relation to energy, the first initiatives were taken after the energy crisis in the mid-1970s, where campaigns, advertisements, and brochures were aimed at changing the routines of daily life, e.g., by lowering the temperature of the dwelling and turning off lights. Also, considerable subsidies were given for thermal insulation of dwellings and double glazing, and later to installation of renewable energy, e.g., in the form of solar hot water systems. In relation to heat consumption, the stabilization can also, be attributed to legislation on heat planning which introduced a so-called connection duty to the district heating system for a series of residential areas, limiting the alternatives for individual consumers. Furthermore, tightening of the building regulations concerning standards of insulation has ensured relatively low energy consumption in new houses. In time, consumer-oriented initiatives have been expanded by including new issues, such as recent campaigns to shut off standby consuming appliances and subsidies to support conversion from electric to district heating. Finally, a special area of focus has been the compulsory energy labelling of electrical appliances, which has resulted in an increased sale of A-labelled refrigerators from under 5\% in 1996 to over $70 \%$ in 2003 (Fjordbak, 2005). Since 1997, many of these initiatives have been organized and promoted by The Electricity Saving Trust, which is an independent public fund with a budget of 13 million EURO to promote electricity efficiency. In spite of all these initiatives, however, energy consumption has only stagnated and not directly decreased.

\section{Developments in housing practice}

Concurrently with sustainable consumption initiatives, other factors have tended to increase consumption related to housing and thus partly outweighed the positive effects of policy initiatives. During the last ten years, consumers have invested heavily in dwelling renewals, particularly in the installation of new kitchens and recently also new bathrooms (IFKA, 2005). Housing standards have thus improved, both in relation to the increased number of square meters (see figure 2), and in relation to house equipment, e.g the electric appliances in homes (see figure 3). 


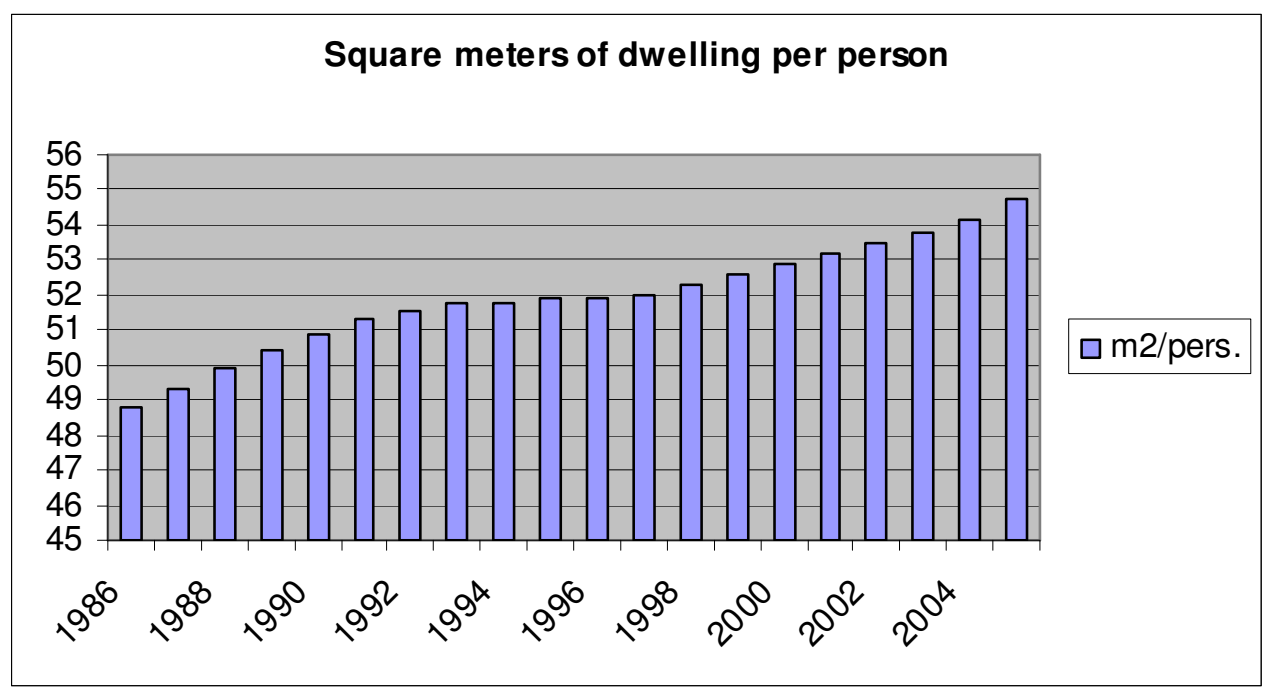

Figure 3: Development in square meters of dwelling size per person (StatBank Denmark, 2005).

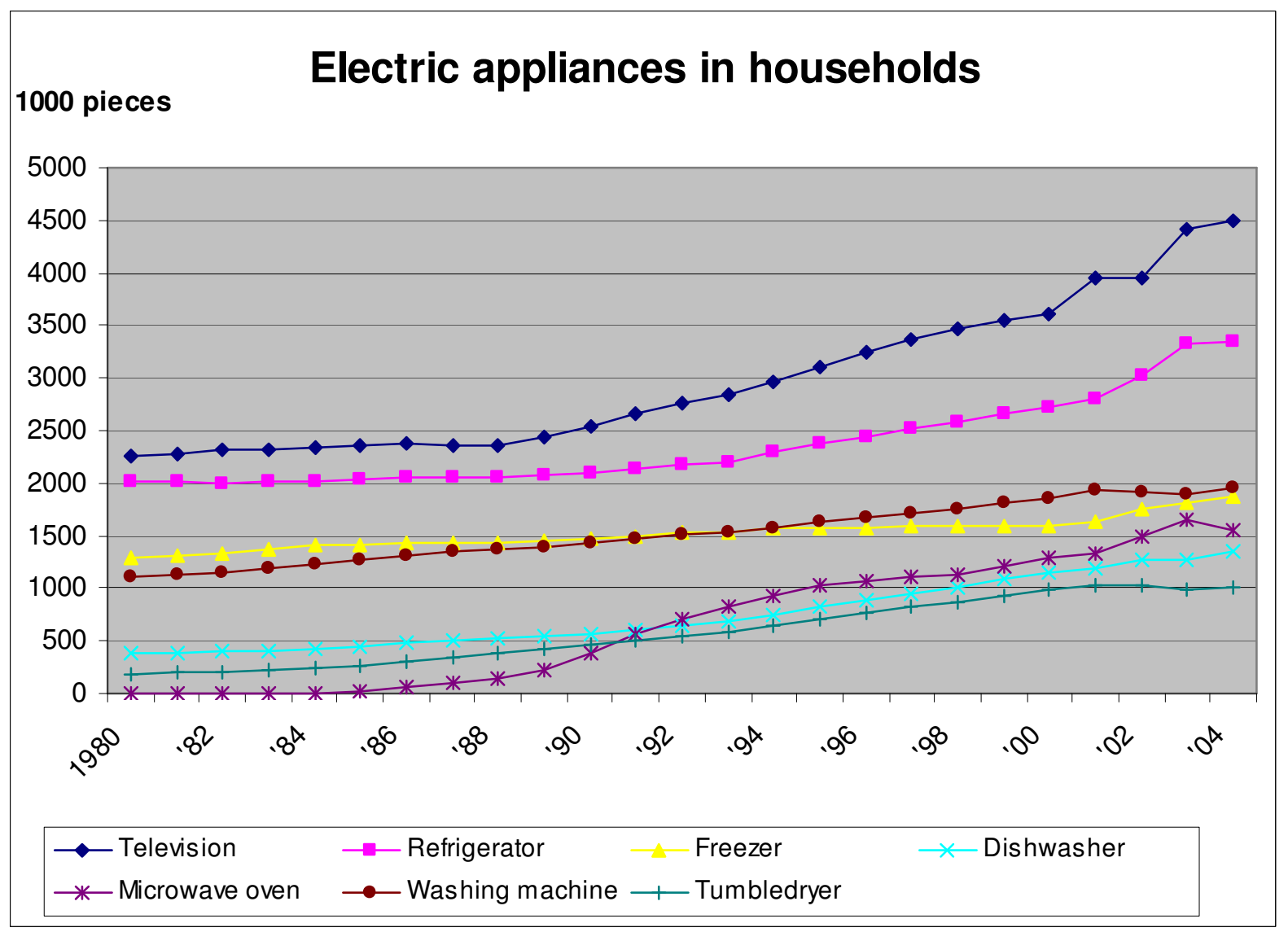

Figure 4: Development in electric appliances (Danish Energy Authority, 2003). 
Improvements in the energy efficiency of appliances are thus balanced by the growing number of appliances, resulting in a stable level of electricity consumption. Correspondingly, improvements in the insulation of houses have been balanced by the growing number of square meters that it is necessary to heat (the total heated area has increased even more than figure 2 illustrates, since the population has grown 5.8\% during the period) (Danish Energy Authority, 2005). Estimates show that economically feasible renovations of Danish homes could reduce total heat consumption by one-third (Wittchen, 2004). Research on why houseowners do not make these energy investments indicates that houseowners prefer to invest time and money in improving the standard of their houses instead of making energy saving renovations, even though these might be economically advantageous (Gram-Hanssen et al., Forthcoming). The dynamics behind these types of rising housing standards have not yet been addressed by sustainable consumption policies, and to illustrate this blindspot, we include a few words on the recent boom in bathroom renovations.

Since the mid-1990s, the number of housing renewals have maintained an unusually high level, due to a combination of growing incomes, extraordinary increases in property values, and the introduction of more advantageous types of mortgage loans (IFKA, 2005). During this period a long-term trend of kitchen replacements and renewals has been supplemented by an increasing focus on bathroom replacements and renewals. A representative poll carried out by Rassing and Thulstrup shows that 5.2\% of Danish households installed a new bathroom in 2004, thus indicating that bathrooms have become an important part of renovation expenditures (Rassing and Thulstrup, 2004; unfortunately, available statistics do not give detailed quantitative information on the kind of renovations carried out). Part of the renovation trend consists of adding more bathrooms to existing dwellings, motivated by the congestion and bottlenecks that have intensified due to changing showering habits - from the weekly bath or shower to the daily (or twice daily) shower - and due to the increasing time pressure in everyday life (Quitzau \& Røpke, forthcoming). The same trend is highlighted for the UK in Hand et al. (Hand et al., 2005). Simultaneously, the functions of the bathroom have changed as well as the visions of how a desirable bathroom should look. Whereas the bathroom was previously mainly related to hygiene and functionality, it now seems to be undergoing a change where new meanings become more dominant. The bathroom has in many ways become a room for well-being, as it provides a refuge for engaging in personal pleasure and a break from a hectic daily life. This is reflected in the focus on the aesthetics of the room, the 
convenience of floor heating, and the installation of new equipment like spas, luxury showerheads, and built-in music centres. Of course, the development is strongly supported by the advertising strategies of the bathroom industry, and the media play an important role with their increasing focus on how to re-arrange and further develop bathrooms. In this way, visions of aesthetic bathrooms with new contexts of use and greater selections of equipment, materials, and design have changed the bathroom into a field for expression of individual taste and identity (Quitzau, 2004; Quitzau \& Røpke, forthcoming).

\section{Case 2: Transport}

There is a broad array of environmental and societal problems connected to motoring. Air pollution, use of scarce resources and congestion are obvious consequences, but also accidents, obesity, and lack of fitness are partly results of increased car use. The positive side of motoring is increased mobility (for car owners), and this dilemma between mobility and its negative side-effects is one of the profound dilemmas of modern societies. The dilemma is reflected in the limited initiatives aimed at promoting sustainable consumption policies in the area of transportation.

\section{Development of consumption during the last 20 years}

Only 50 years ago it would be unusual for a family to have a car. In the 1970s, car ownership became normal in the middle classes and today 61\% (2004) of all Danish households have access to a car (StatBank Denmark, 2005). Thus, private transport is a consumption area in rapid growth. Car traffic has doubled during the past 20 years (figure 5), while cycling has shown a slight decline (Road Directorate, 2004). Considering the steady rise in the number of cars, nothing indicates that this will change (StatBank Denmark, 2005). The growth in car transport follows the general economic growth, and there is no sign of a decoupling between economic growth and energy use in the transportation sector, as is seen, e.g., in domestic heating (Bach et al., 2005). 


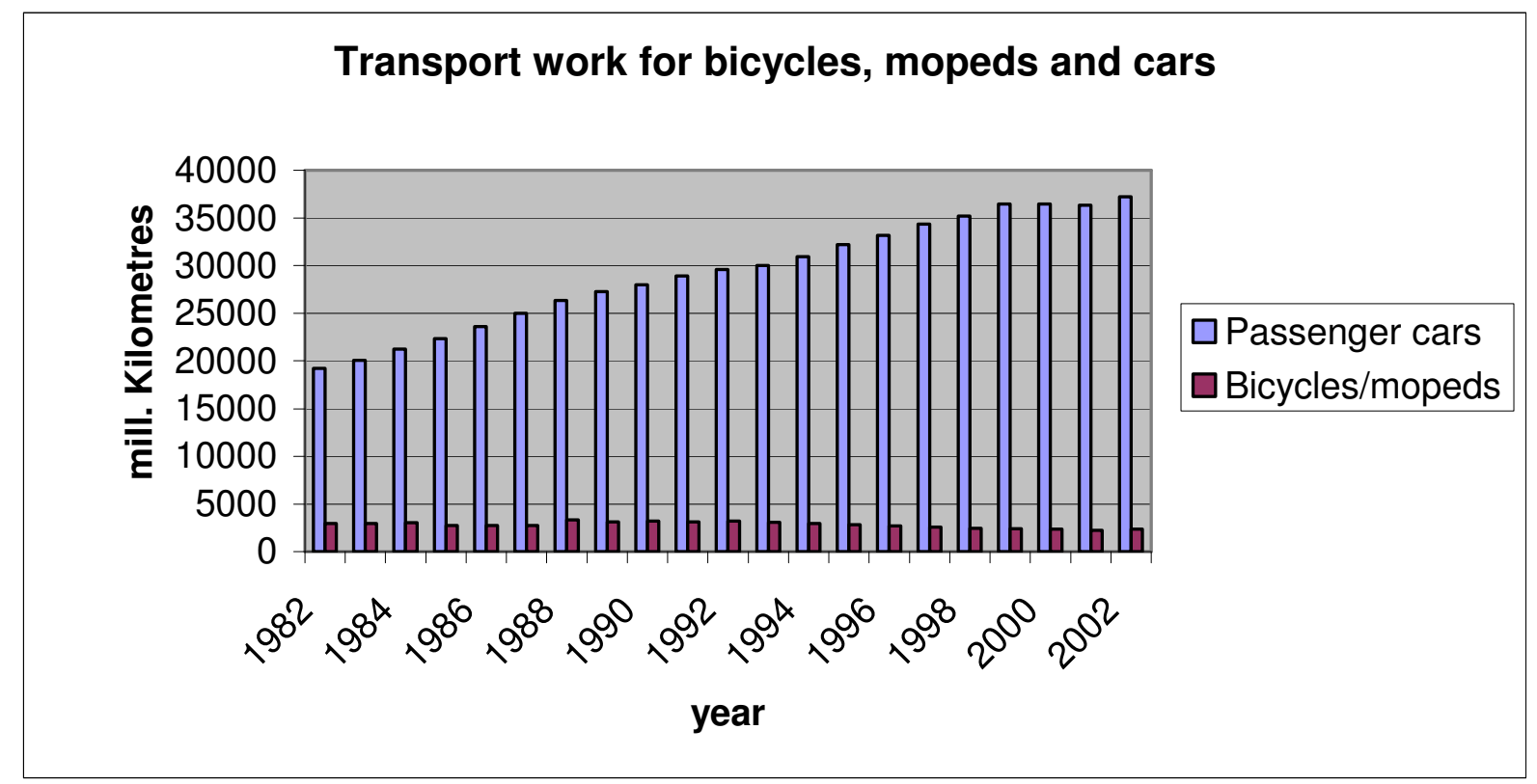

Figure 5: Transport work by bicycles/mopeds and passenger cars in millions of kilometres per year (Road Directorate, 2004).

\section{Sustainable consumption policy initiatives}

Transport has many environmental effects and throughout the last 20 years different initiatives have been taken in order to reduce the pollution from transport in Denmark. In 1997, a green tax based on calculations of the cars' energy efficiency replaced the earlier tax on motor vehicles calculated according to weight. The green tax serves as an economic incentive to buy cars with higher energy efficiency. Simultaneously, more energy efficient cars were introduced on the market, and the result is that the new cars sold in Denmark overall have become generally more energy efficient (figure 6). But still, this rise in efficiency cannot at all counterbalance the growth in transportation. 


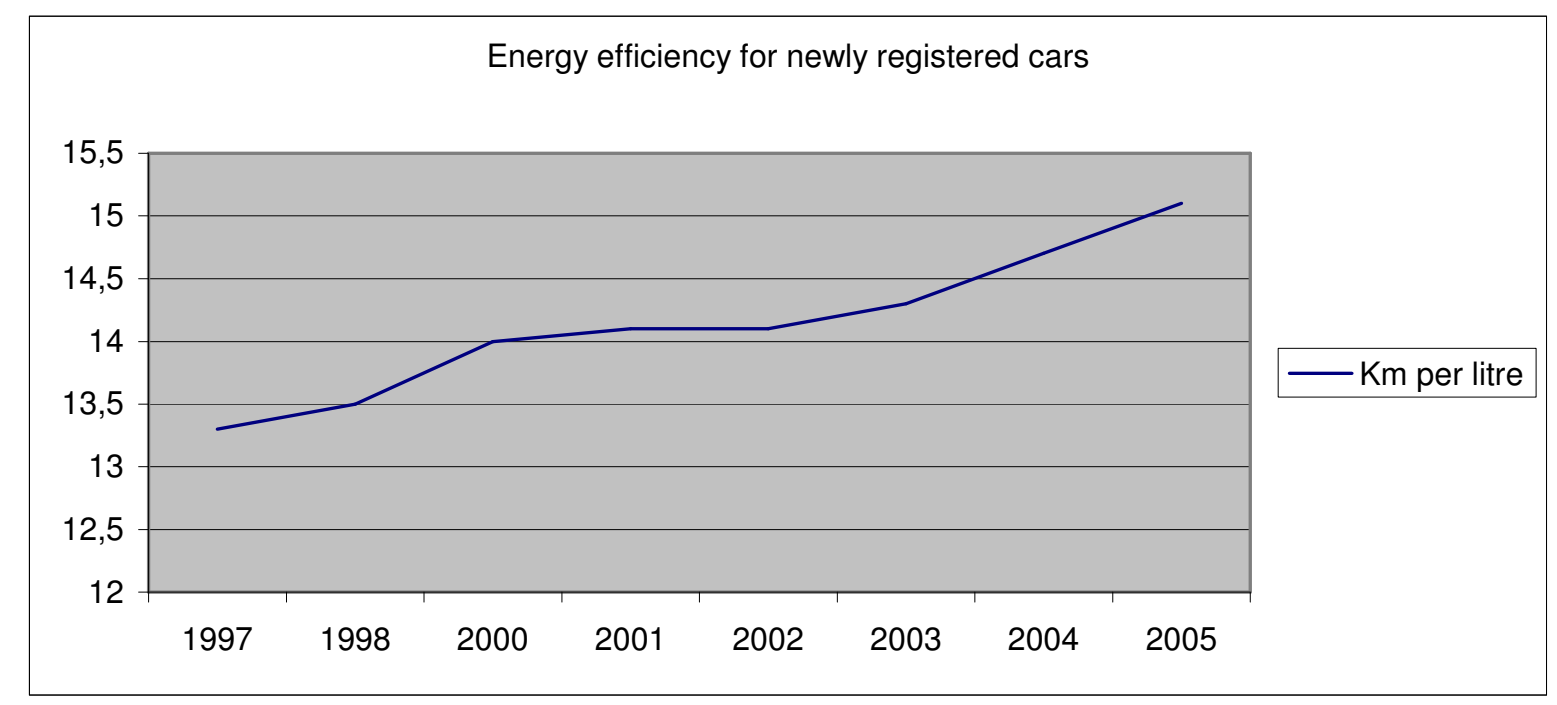

Figure 6: Fuel consumption for newly registered cars (StatBank Denmark, 2005).

A positive effect of environmental regulation is the decline in the emission of $\mathrm{NO}_{\mathrm{x}}$ and hydrocarbons. These emissions have been uncoupled from the growth in transport as a result of a law from 1990 requiring new cars to have catalysts (Bach et al., 2005). The phasing out of lead in petrol in the period 1978-1994 is another success. This development was supported by lower taxes on lead-free petrol. It is characteristic for these environmental successes that they are based on technological development and did not demand changes in daily practices. The introduction of catalysts and more energy efficient cars only requires behavioural changes that are limited to the car buying situation, where these technologies are promoted through economic incentives, ecolabelling, and information campaigns.

Some municipalities have tried to influence travel behaviour through campaigns and local initiatives. An example is the European mobility week and the Car Free Day, where many Danish municipalities arrange events and activities. Some municipalities have established mobility centres that aim, e.g., at promoting car-pooling, bus transport to big companies, and cycling. Some towns promote themselves as being cycle-friendly. Denmark's Road Safety and Transport Agency launched a campaign in 2003-2004 that tried to make Danes buy more energy efficient cars and to teach people to learn more energy efficient driving practices (Denmark's Road Safety and Transport Agency, 2003). Since 1997, the NGO, Danish Cycling Federation, has carried out a campaign where Danish workplaces compete on having the most employees who cycle to work. This campaign is very popular, with about 100,000 participants every year since 2001 (Danish Cycling 
Federation, 2006). Originally, the campaign was supported by The Green Foundation, but today it is financed by the participants and the organizers.

\section{Developments in transport practice}

Although some initiatives have been taken to reduce the environmental effects from transport, other policies simultaneously support a growth in mobility. E.g., a tax-free allowance is provided for people who commute more than $20 \mathrm{~km}$ a day, which encourages people to settle far from their workplaces. This scheme has even been expanded under the right-wing government (which came into power in 2001) with an increased allowance for people in remote areas. The main political arguments concern the importance of a mobile workforce and the need for preventing the depopulation of remote areas. But these tax-free allowances institutionalize the long work trip and settlement in provincial towns, and result in increased car dependency. Other policies promoting motoring are: Company car arrangements, where employees do not pay for the car according to their use, but instead pay a fixed amount; a rule saying that unemployed people are obliged to accept job-offers that involve several hours of transport every day; and finally, reduction of the subsidy to public transport, with the result that public transport has become much more expensive relatively in comparison with private car transport during the past 20 years (European Environment Agency, 2000; NOAH-trafik, 2003; Pedersen, 1999). Altogether, social and institutional structures are developed where individual considerations of economy and time make motoring beneficial or directly necessary.

But the growth in private transport cannot be explained by the development of certain socioeconomic structures alone. Driving as an everyday practice gives an experience of time-efficiency, individual freedom and independence. The opportunity to do things spontaneously is often emphasized in studies on travel mode choices. This is in accordance with the fact that leisure travel counts for $40 \%$ of the total amount of private transport (Bach et al., 2005). An interesting aspect is that it can be much more important to have the possibility to do things than it is to realize these possibilities (Godskesen, 2001). This emphasizes the car's symbolic value, giving its owner a feeling of individual freedom to choose between many different experiences and activities.

Also the technological development of the Danish transportation system is increasingly centred around the car. Bus traffic has been reduced and the highway system has been expanded, so 
Denmark today has the highest amount of highway kilometres per inhabitant in Europe. Seen in relation to Danes' disposable income, cars have become much cheaper since 1980 (European Environment Agency, 2000; Pedersen, 1999). This economic development has made car purchase possible for a new, large group of people and is an important precondition for the growth in private transport.

Mobility is seen as a precondition for economic growth: Therefore, transport is a consumption area with strong contradictions between environmental and economic concerns. This dilemma is reflected on many different levels. There is an obvious contradiction between the policy aim to reduce $\mathrm{CO}_{2}$ emission and the actual transport policies, where cars become cheaper and the road system is extended. From a regional point of view, there is a dilemma between preserving natural resorts and promoting economic growth in the area, e.g., in relation to discussions on extensions of the highway system. Also on the individual level, there are dilemmas related to the collective effects of individual choice. This can be illustrated by the father who chooses to drive his own daughter to school, because he is very busy and because there are so many cars around the school area that he does not consider it safe for her to cycle to school.

\section{Case 3: Information and Communication Technology (ICT)}

A number of environmental problems are related to the use of ICT. These problems include the use of energy to manufacture and use ICT products as well as local environmental and health-related problems in relation to the extraction of materials used in ICT (such as copper, gold, and mercury). Also, some of these materials are scarce resources (e.g., copper, tin, and nickel). Finally, problems are associated with the management of compound electronic waste, which contains harmful substances such as mercury and brominated flame retardants that are difficult to isolate and recycle (DEPA, 2001; DEPA, 2003).

Therefore, even if the consumption of ICT is not comparable to housing and motoring in quantitative terms, the side-effects - especially in relation to the extraction of metals and the management of electronic waste - makes ICT an important area to study from an environmental perspective. 


\section{Development of consumption during the last 20 years}

ICT is one of the most rapidly evolving areas of consumption - particularly, modern ICTs such as mobile phones, computers, and the Internet. Between 1995 and 2004, the share of Danish families owning one or more personal computers doubled from $37 \%$ to $84 \%$. In 2004, $75 \%$ of the Danish population had access to the Internet at home and half the population (53\%) used the Internet on a daily basis. The ownership of mobile phones more than quadrupled between 1995 and 2004 from $20 \%$ to $91 \%$. (Statistics Denmark, 2004)

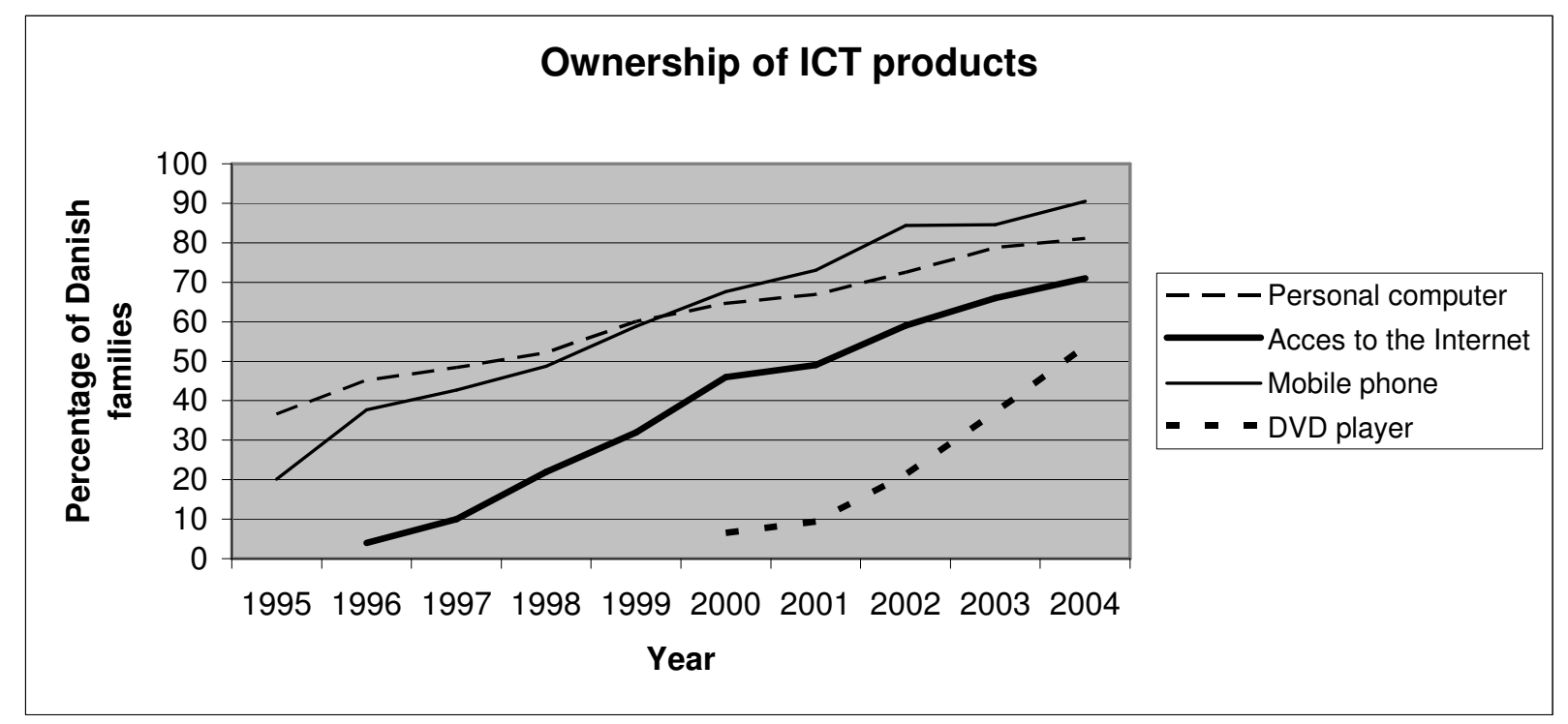

Figure 7: The development in families' ownership of ICT (Statistics Denmark, 2004; Statistics Denmark, 2005).

As figure 7 shows, modern ICT constitutes a consumption area with high growth rates. Modern ICT makes it possible to study the introduction of new technologies and their integration into everyday life "while it is happening".

The growing number of electrical appliances, including ICT products, in households outweighs to a great extent the gains made through improved energy efficiency (European Environment Agency, 2005). Especially, the increasing electricity consumption by electronic appliances in standby mode is attracting the attention of both researchers and policy makers, and studies indicate that about $9 \%$ of Danish residential electricity use can be attributed to standby power consumption (GramHanssen, 2005; Gram-Hanssen \& Gudbjerg, 2006). Due to a lack of statistical data, it is impossible 
to estimate the development in the amount of electronic waste from Danish households, but it seems reasonable to assume that increasing consumption of electronic appliances eventually results in growing waste production.

Of the total amount of electric/electronic waste (refrigerators and freezers excluded) about $75 \%$ was collected and handled separately from ordinary waste in 2001 , while the remainder was either deposited (10\%) or combusted (15\%) (DEPA, 2003). For some product groups, the share of deposited and combusted waste is considerably higher - e.g., only $50 \%$ of all NiCd batteries were collected separately in 2004 (Maag \& Hansen, 2005).

\section{Sustainable consumption policy initiatives}

Unlike housing and transportation, very few political initiatives have been taken on the national level to manage the consumption of ICT from an environmental point of view. On the contrary, increased use of tele-mediated communication is regarded in itself as an absolute asset for the economy as well as the public. Since the 1990s, ICT has been assigned a key role in governmental papers and strategies for the building of a modern "knowledge and information society" (Ministry of Research, 1994; Ministry of Trade and Industry, 1996). According to a recent publication from Statistics Denmark and the Ministry of Science, Technology and Innovation, the use of ICT should "contribute to create growth in the Danish business sector, to modernize the public sector and to qualify Danes for the future knowledge society." (Statistics Denmark \& Ministry of Research, 2004, p. 11 - our translation).

Public awareness has only in few cases been drawn to the environmental aspects of the use of ICT. In a national campaign on television, citizens were encouraged to turn off their electrical appliances instead of leaving them on standby. Another campaign encouraged people to replace their old computer monitors with flat monitors, which consume less energy. Also, there have been campaigns on the importance of separating used electrical appliances and batteries from ordinary waste.

National campaigns have predominantly focused on waste handling and energy use, whereas no campaigns have addressed the lifetime of ICT products. Due to a high frequency of replacements of "old" ICT products with new ones, the average lifetime of ICT is generally short. For instance, the 
estimated lifetime of mobile phones is only 18 months (IMS, 2006). Increasing the average lifetime would reduce the environmental impact from manufacturing ICT products (including problems related to the extraction of materials) and result in lower quantities of compound electronic waste from households. However, due to the general improvements in the energy efficiency of many new ICT products (e.g. flat screens compared to bulb-based screens, and laptop computers compared to stationary PC's), lower turnover rates might in some cases result in a smaller reduction of the energy consumption. Thus, increasing the average lifetime of ICT products can in some cases be in conflict with the intention of reducing the energy consumption in the use phase. On the other hand, increasing standards to some extent outweigh the benefits from replacing old products by new ones; for instance, the improvements of flat screens (compared to bulb-based screens) are to some extent counterbalanced by the purchase of larger television as well as computer screens.

Since most ICT products are imported, also international initiatives such as the American "Energy Star" label and the EU directives WEEE (on Waste of Electric and Electronic Equipment), RoHS (on the Restriction of the use of certain Hazardous Substances in electrical and electronic equipment), and EuP (on the eco-design of Energy-using Products) affect the environmental impact related to Danish consumption of ICT.

The WEEE directive assigns the responsibility for collecting and handling electric and electronic waste to the producers and importers of electric and electronic products. By doing this, the aim is to encourage producers to improve the design of their products so as to reduce the environmental impact and to make it easier to recycle and handle electronic waste. The WEEE directive became effective as of 1 April 2006. In Denmark, a large group of producers and importers of electric/electronic products has established a joint scheme, called Elretur, for collecting and handling electronic waste (Elretur, 2006).

Separating used electrical appliances from ordinary waste is a prerequisite for a successful implementation of the WEEE directive. Consumers therefore become an important actor, and since much electronic waste from households is not separated from ordinary waste, there have been various campaigns in television and newspapers on the importance of sorting waste. 


\section{Development in communicative practices involving ICT}

In relation to ICT, the rapid innovation of products and technologies plays a particularly important role. Within the area of computer technologies, the innovation of new products is closely related to the continuous improvement of the hardware towards increased processing power and storage capacity concurrently with the development of new and more "heavy" software programmes. With regard to communication technologies (especially mobile phones), the innovation of new products is characterized by a continuous addition of new features such as electronic calendars, Multimedia Messaging Services (MMS), and video cameras in combination with frequent changes of the exterior design. The rapid product innovation makes existing ICT products obsolete long before the actual decay of the technology and explains the frequent replacement of old products with new ones.

From an everyday life perspective, the use of ICT is closely related to families' management of the social conditions of modern family life. The process of individualization and emancipation acts as a kind of centrifugal force on the family as a social unit (Dencik, 1996), and the need for telemediated communication and coordination is intensified by the temporal and spatial dispersion of family members and their individual activities due to the increased spatial distribution of activities and services in modern society (Ling, 2004). Following from this, the frequent use of mobile phones can be interpreted as creating an experience of "tele-mediated proximity" between family members (Christensen, Forthcoming). Communication technologies have become an integrated part of the continuous production and reproduction of close and intimate relations. As a consequence, the use of ICT may - in the long run - enable further dispersion of family members. Also outside the family, ICT has become an integral part of the management of social relationships with relatives, friends, and colleagues (Fortunati, 2005; Licoppe, 2004).

Thus, the growth in consumption of ICT products is driven by a co-evolution between, on the one hand, technological changes in the form of rapid product innovation in combination with infrastructural development (e.g., increased mobility) enabling further dispersion of activities and services; and, on the other hand, changes within social relations and socio-economic institutions such as individualization and emancipation in combination with increasing specialization and spatial distribution of activities and services. Together, these changes constitute a strong driving 
force behind the growth in consumption of ICT and its environmental impact, which has only to a very limited extent been addressed by sustainable consumption policies.

\section{Evaluating the Impact of Consumer-oriented Environmental Policies}

The case studies show that the consumer-oriented environmental policy has had an effect on private consumption, more in some areas than in others. In the following, we discuss the general characteristics of the successes and failures, and finally bring into focus the aspects of consumption that are not thematized in an environmental perspective.

The most remarkable success stories of sustainable consumption are the reductions of water use, a rise in efficiency for electrical appliances and heating systems, the phasing out of lead in petrol, and the uncoupling of $\mathrm{NO}_{\mathrm{x}}$ and particle pollution from the growth in private transport. The stabilization of energy consumption in households is primarily caused by a replacement of old products with new, more energy efficient (e.g., A-labelled) freezers and refrigerators and by insulation of buildings. The phasing out of lead was effected by introducing alternative types of petrol, and the reduction in particle pollution was obtained by catalysts and motors with cleaner combustion. In all cases, cleaner or more efficient technologies have been developed; and they have become widespread through a combination of policy instruments such as labelling, subsidies and considerable taxes on electricity and water. Daily behaviour has been addressed by information campaigns drawing attention to the importance of conserving Danish ground water and saving energy. Very simple advice concerning sustainable behaviour has been disseminated through brochures, television campaigns and the like. Apparently, sustainable consumption policies are successful when technological development, economic structures (taxes and subsidies), information (labelling), and understanding (campaigns) are all in accordance with each other.

In some areas of consumption, a rise in efficiency covers a growth in end-consumption. This is the case in the partially successful effort to keep energy use in Danish households constant during the last two decades. Technological development, economic instruments, and a rise in awareness of energy use have made it possible to lower energy consumption. But simultaneously, the houses have become bigger and the number of appliances has increased, resulting in unchanged energy consumption. In studies on the so-called rebound effect, it is argued that increasing energy efficiency directly contributes to increasing the demand for energy, for instance, because the related 
economic savings can be spent on increasing quantities of the same good or for other energyconsuming purposes (see e.g. a special issue of Energy Policy, 2000). We cannot include the complex discussion on the rebound effect in this paper, but it is worth noting that such a big effort is made to optimize energy efficiency and increase people's awareness of energy use, while the increase in standards of living is not addressed at all. Increasing standards of living - or in other words, increasing aggregate consumption - would not be so environmentally problematic if, with increasing income, people chose to increase only the standard of the less resource-intensive activities such as the care for children and elderly or the enjoyment of having massage, but as the examples of this paper demonstrate, the resource-intensive activities are in high demand when people become richer.

The development of more efficient cars shows the same pattern - only here, the rise in efficiency cannot at all keep up with the growth in private transport. There have been sporadic initiatives aimed at reducing the environmental impact of transport and also campaigns trying to influence modal choices, but effective economic instruments have not been applied (Bøgelund, 2003). The effect has been very limited and all initiatives are overtaken by the growth in transport, which is out of control. An explanation is that transport is ascribed great importance for the general growth and development of society. Therefore, a policy furthering mobility is pursued and this is in opposition to the environmental goals. This leads to the conclusion that it is obviously more difficult to influence consumption patterns when the policy goals are ambiguous.

Another important characteristic is the meaning we connect to different consumer goods or activities. It is thought-provoking that refrigerators, toilets, and petrol are all "invisible" consumer goods that are not used in a symbolic way, while the dwelling size, the bathroom, some ICT products like mobile phones and, to an even greater extent, cars, are important in order to show success, status, and individual freedom. It would be very easy to draw the conclusion that environmental policies can be successful in consumption areas where the goods or activities are "invisible". But this conclusion would fail to recognize the dynamic character of consumption patterns. In the United States, big refrigerators are very common, and they are now being promoted in Denmark. Will the Danish conception of a fridge being "just a fridge" change in the future? Also water consumption has potential for change. Danes are very much aware of saving water, but as mentioned in the housing case, the symbolic meaning of the bathroom is changing and new water 
consuming technologies are being installed. These examples show how the symbolic dimension in some cases can redefine the meaning and status of a technology and influence the effect of environmental policies.

Many areas of consumption are not addressed by environmental policy and environmental aims do not exist. While it is generally accepted to make campaigns about not wasting water and energy, the 'normal' consumption of products such as renewal of mobile phones, improving the dwelling or buying new clothes is not addressed in the sustainable consumption policy. Altogether, the standard of a 'normal' everyday life has changed the past 20 years. It has become normal to have at least one car in a household, and the standard of dwellings has improved, both with regard to size and equipment. The latest development is in the area of ICT where telephones and computers are now becoming individually owned products integrated into more and more practices of everyday life.

This growth in normal consumption is driven by different dynamics. The rapid technological development is obviously a strong driving force in the ICT area, but it also influences renewals of the dwelling. Individualization combined with economic progress results in families purchasing more than one television, telephone, car etc. Finally, people acquire new technologies - such as microwave ovens and extra bathrooms and cars - to ease time pressure in everyday life. Also the need to withdraw from stressful everyday life can create new consumption, as in the example of the bathroom that becomes a refuge for relaxation - setting new standards for bathroom equipment.

Obtaining the 'right' standard in different areas of consumption is closely connected to identityformation, e.g., having the 'right' house is part of being a successful family. This makes it difficult to question the size and equipment of the dwelling from an environmental perspective, because living up to environmental goals would mean that the family should do without some of the facilities that belong to a 'normal' home. What a family 'needs' cannot be seen out of context with the normal standard of the social group to which it belongs. Also commercials are an important element in constructing a higher level of 'normal' consumption. The result is that the expectations of normal consumption are imperceptibly rising all the time and environmental policy is not thematizing this development. 


\section{Conclusion and Perspectives}

Developments in private consumption in Denmark in relation to housing, transport, and ICT have been studied in order to evaluate the impact of Danish consumer-oriented environmental policies in recent decades. The consumption practices have been studied through a theoretical perspective that emphasizes the intertwinement of material objects, social relations, and symbolic meanings in consumers' daily practices.

The case studies show how the environmental effects of consumption in some areas have been reduced due to consumer-oriented environmental policies - especially within households' water consumption and also to a lesser degree within households' energy consumption - whereas growth in transport and ICT shows the limits of these policies. The successes are mainly related to substitution with more efficient technologies that are not strongly related to social status and do not have great importance for overall economic growth, e.g., refrigerators and toilets. The opposite holds true for the areas of transport and ICT, where we have seen very limited environmental improvements, and where the energy consumption continues to grow. These areas are characterized by having major importance for the economy, the individual's social status and, especially for ICT, also being characterized by rapid product innovation.

Both the character of the actual policies, including their ability to address the complex nature of daily practices (involving material, social, and symbolic aspects), and the character of the practices in question, e.g., significance and status in daily life, seem to influence whether the policy is successful or not. Based on these analyses, it is concluded that consumer-oriented environmental policy in some areas has succeeded, even though these successes are characterized by the principle of 'picking the lowest hanging fruits', meaning that improvements are only made when they are easy to reach and do not conflict with other goals. Throughout the years, Danish consumer-oriented environmental policy has been limited to working with areas that do not conflict with a growthoriented policy. It has furthermore been based on a static understanding of consumption, without considering in any detail the driving forces of consumption growth.

The article illustrates how sustainable consumption policies can be undermined by conflicting driving forces behind consumption growth and by the gradual changes of what is considered to be normal everyday practices. Many other forces than those considered here could be added to the 
bleak perspective, such as the importance of the extremely cheap products emerging from the global sweatshops, as highlighted by Juliet Schor (Schor, 2005), and the trend towards increasing private consumption at the expense of the less environmentally detrimental public consumption (Røpke, 2001a). However, other forces - with little or no relation to environmental considerations - may promote more sustainable consumption patterns. This point is emphasized in two studies on sustainable consumption in France and the USA (Cohen et al., 2005; Sanches, 2005). Sustainable consumption policies have been weakly developed in both countries, and environmental concerns have been low on consumers' agenda, but other issues have influenced consumption attitudes and behaviour in a sustainable direction. In France, the introduction of the 35-hour week has stimulated self-reflection among consumers and encouraged a reassessment of values related to consumption so that less commoditized activities have been favoured and more time is spent together with friends and family. In the USA, there has been an upsurge in lifestyle reinventions, such as different forms of voluntary simplicity motivated by concerns for family and community life and for personal fulfilment. Both countries have experienced anti-consumerist protest campaigns aimed at advertising and commercial television, and anti-consumerism has also been revived in relation to different aspects of globalization. Although these trends are relatively marginal compared to the dominant forces driving consumption growth, it would be interesting to look for the potential, also in further studies of the Danish case. Changing consumer values and priorities might also open up the possibilities for more radical sustainable consumption policies, addressing aggregate consumption and ever increasing standards. The first step towards such changes is to place the issue of volume-of-consumption effects high on the agenda.

\section{Acknowledgements}

We gratefully acknowledge the detailed and useful comments from the editor, John Thøgersen, and two anonymous referees.

\section{Reference List}

Andersen, J. (1997). Hverdagens centrifuge (The centrifuge of everyday life). Århus: Hovedland.

Andersen, M. S. (1989). Miljøbeskyttelse - et implementeringsproblem (Environmental protection - a problem of implementation). Politica, 21(3), 312-328. 
Andersen, M. S. (1997). Denmark: the shadow of the green majority. In: M.S. Andersen \& D. Liefferink (Eds.), European environmental policy. The pioneers, pp. 251-286. Manchester: Manchester University Press.

Bach, H., Christensen, N., Gudmundsson, H., Jensen, T. S., \& Normander, B., Eds. (2005). Natur og Miljф 2005. Påvirkninger og tilstand (Nature and environment 2005. Impacts and state). Copenhagen: National Environmental Research Institute, Ministry of the Environment.

Bartiaux, F. (2006). Do information and awareness work? Mental compartmentalisation and consumers' behaviours. Proceedings: Changes to Sustainable Consumption, 20-21 April 2006, Copenhagen, Denmark. Workshop of the Sustainable Consumption Research Exchange Network (www.score-network.org).

Beck, U. (1992). Risk society - Towards a new modernity. London: Sage Publications.

Beckmann, S. C. (1998). Ecology and consumption. In: P. Earl \& S. Kemp (Eds.), The Elgar Companion to consumer research and economic psychology, pp. 170-175. Cheltenham, UK: Edward Elgar.

Beckmann, S. C., Brokmose, S., \& Lind, R. L. (2001). Danske forbrugere og $\phi$ kologiske fødevarer - ØKO foods II projektet (Danish consumers and organic foodstuffs - The ECO foods II project). Copenhagen: Handelshøjskolens Forlag.

Bonke, J. (2002). Tid og velfard (Time and welfare). Copenhagen: Socialforskningsinstituttet.

Bygge og Boligstyrelsen (1997). Changes to the Departmental order no. 891 on individual metering of electricity, gaz, water and heat. Downloaded from: http://www.energitilsynet.dk/lovgivning-oganmeldelse/2/love-og-bek-varme/bek-om-aendring-af-bekendtgoerelse-om-individuel-maaling-afel-gas-vand-og-varme/.

Bøgelund, P. (2003). Greening the area of car taxation? A comparative study of Environmental Policy Integration in Sweden and Denmark. Aalborg: Aalborg University.

Campbell, C. (1994). Consuming goods and the good of consuming. Critical Review, 8 (4), 503520. 
Christensen, T. H. (Forthcoming). Tele-mediated proximity: so near, yet so far. Submitted for review.

Cohen, M. J. (2005). Sustainable consumption in national context: An introduction to the special issue. Sustainability: Science, Practice, \& Policy, 1 (1).

http://ejournal.nbii.org/archives/vol1iss1/0410-008.cohen.pdf

Cohen, M. J., Comrov, A., \& Hoffner, B. (2005). The new politics of consumption: Promoting sustainability in the American marketplace. Sustainability: Science, Practice, \& Policy, 1(1). http://ejournal.nbii.org/archives/volliss 1/0410-011.cohen.pdf

Danish Cycling Federation (2006). We cycle to work - campaign. URL (http://www.vcta.dk) Access date 8-5-2006.

Danish Energy Authority (2003). Energy in Denmark 2003. Copenhagen: Danish Energy Authority. Danish Energy Authority (2005). Energy Statistics 2004. Copenhagen: Danish Energy Authority.

Dencik, L. (1996). Familjen i välfärdsstatens förvandlingsprocess (The family in the transformation process of the welfare state). Dansk Sociologi, 7 (1), 57-82.

Denmark's Road Safety and Transport Agency (2003). Hvor langt på literen? (How far pr litre?). Copenhagen: Denmark's Road Safety and Transport Agency.

DEPA, Danish Environmental Protection Agency (1999). Intensified Product-oriented Environmental Initiative. Copenhagen: Danish Environmental Protection Agency.

DEPA, Danish Environmental Protection Agency (2001). Miljøspecifikationer for elektroniske teleog dataprodukter (Environmental specifications for electronic tele- and dataproducts). Copenhagen: Danish Environmental Protection Agency.

DEPA, Danish Environmental Protection Agency (2003). Affaldsstrategi 2005 - 2008 (Waste strategy 2005 - 2008). Copenhagen: Danish Environmental Protection Agency.

Elretur (2006). URL (http://www.elretur.dk) Access date 8-5-2006.

Energy Policy (2000). Special Issue on the rebound effect. Energy Policy, 28, Issue 6-7. 
European Environment Agency (2000). Bevager vi os i den rigtige retning? Indikatorer for transport- og miljøintegrationen i EU (Are we moving in the right direction? Indicators for integration of transport and environment in the EU). Copenhagen: European Environment Agency. European Environment Agency (2005). Household consumption and the environment. Copenhagen: European Environment Agency.

Fjordbak, T. (2005). On sale of A-labelled refrigerators and freezers during the last 20 years. Copenhagen: IT Energy APS.

Fortunati, L. (2005). Is body-to-body communication still the prototype? The Information Society, $21(1), 53-61$.

Fuchs, D. A., \& Lorek, S. (2005). Sustainable consumption governance: A history of promises and failures. Journal of Consumer Policy, 28 (3), 261-288.

Gatersleben, B., \& Vlek, C. (1998). Household consumption, quality of life, and environmental impacts: A psychological perspective and empirical study. In: K. J. Noorman \& T. S. Uiterkamp (Eds.), Green Households? Domestic Consumers, Environment, and Sustainability, pp. 141-183. London: Earthscan Publications.

Godskesen, M. (2001). Rutiner og brud i hverdagens transport (Routines and ruptures in everyday transport). Lyngby: Technical University of Denmark.

Gram-Hanssen, K. (1998). Evaluering af Den Grønne Fond. Hovedrapport (Evaluation of The Green Fund. Main report). Copenhagen: Miljø- og Energiministeriet.

Gram-Hanssen, K. (2003). Boligers energiforbrug - sociale og tekniske forklaringer på forskelle (The energy consumption of dwellings - social and technical explanations of differences). Hørsholm: Statens Byggeforskningsinstitut.

Gram-Hanssen, K. (2004). Domestic electricity consumption - consumers and appliances. In: L. A. Reisch \& I. Røpke (Eds.), The ecological economics of consumption, pp. 132-150. Cheltenham, UK: Edward Elgar. 
Gram-Hanssen, K. (2005). Husholdningers elforbrug - hvem bruger hvor meget, til hvad og hvorfor? (Households' energy consumption - who use how much, for what and why?) Hørsholm: Statens Byggeforskningsinstitut.

Gram-Hanssen, K., Kofod, C., \& Nærvig Petersen, K. (2004). Different everyday lives - different patterns of electricity use. In: Proceedings of the 2004 American Council for an Energy Efficient Energy Economy. Summerstudy in Buildings. Washington, D.C.: ACEEE.

Gram-Hanssen, K., \& Gudbjerg, E. (2006). Reducing standby consumption in households - by means of communication or technology. In: Proceedings from ACEEE summerstudy on energy efficiency in buildings. Less is more: En route to zero energy buildings. August 13-18, 2006, Asilomar Conference Center, Pacific Grove, California.

Gram-Hanssen, K., Bartiaux, F., Jensen, O. M., \& Cantaert, M. (Forthcoming). Do home owners use energy labels? A comparison between Denmark and Belgium. Accepted for publication in Energy Policy.

Gronow, J., \& Warde, A. E. (Eds.) (2001). Ordinary consumption. London: Routledge.

Grunert, S. C. (1993). Green consumerism in Denmark: Some evidence from the ØKO foodsproject. Der Markt, 32 (3), 140-151.

Grunert, S. C., \& Juhl, H. J. (1995). Values, environmental attitudes, and buying of organic foods. Journal of Economic Psychology, 16 (1), 39-62.

Halkier, B. (1999). Consequences of the politicization of consumption: The example of environmentally friendly consumption practices. Journal of Environmental Policy and Planning, 1 (1), 25-41.

Hand, M., Shove, E., \& Southerton, D. (2005). Explaining showering: A discussion of the material, conventional, and temporal dimensions of practice. Sociological Research Online, 10 (2). http://www.socresonline.org.uk/10/2/hand.html

Hochschild, A. R. (1997). The time bind. When work becomes home and home becomes work. New York: Metropolitan Books. 
Hoffmann, B., Jensen, J. O., Elle, M., \& Nielsen, S. B. (2005). Water saving strategies and ecological modernisation - transitions, targets, \& tools. Proceedings of the $9^{\text {th }}$ International Conference on Environmental Science and Technology, Rhodes Island, Greece, 1-3 Sept. 2005.

IEA, (2006). Energy Policies of IEA Countries - Denmark, 2006 Review. Paris: International Energy Agency.

IFKA, Institut for Konjunkturanalyse (2005). Det danske køkkenmarked (The Danish kitchen market). Denmark: Institut for Konjunkturanalyse og idé-nyt.

IMS, Informationscenter for Miljø \& Sundhed (2006). Fakta om mobiltelefoner (facts about mobile phones). Copenhagen: URL (http://www.miljoeogsundhed.dk) Access date 8-5-2006.

Iversen, T. (1996). Miljøproblematikken i hverdagslivet. En kognitiv antropologisk undersøgelse af forståelser, handlingsmotivation og handlerum (The environmental problematic in everyday life. A cognitive anthropological study of understandings, motivation and space for action). Master thesis. Department of Anthropology, University of Copenhagen.

Jamison, A. (2001). The making of green knowledge. Cambridge: Cambridge University Press.

Jamison, A., Eyerman, R., Cramer, J., \& Læssøe, J. (1990). The making of new environmental consciousness. A comparative study of the environmental movements in Sweden, Denmark and the Netherlands. Edinburgh: Edinburgh University Press.

Jørgensen, U. (2005). Technology in Denmark - support measures and regulatory efforts. In: T. de Bruijn \& V. Norberg-Bohm (Eds.), Industrial transformation: Environmental policy innovation in the United States and Europe, pp. 175-200. Boston: MIT Press.

Kilbourne, W. E., \& Beckmann, S. C. (1998). Review and critical assessment of research on marketing and the environment. Journal of Marketing Management, 14, 513-532.

Kilbourne, W. E., Beckmann, S. C., \& Thelen, E. (2002). The role of the dominant social paradigm in environmental attitudes. A multinational examination. Journal of Business Research, 55, 193204. 
Kring, C. (2005). Arbejdsliv \& familieliv - Get A Balance (Working life \& family life - Get A Balance). Lyngby: Technical University of Denmark.

Kudahl, S. (2006). Danskerne bliver syge af stress (Danes get ill because of stress). Ugebrevet A4, 5 (10).

Lassen, J. (2002). Politisk forbrug: Miljøet mellem borger og forbruger (Political consumption: The environment between citizen and consumer). In: F. Arler (Ed.), Humanфkologi. Miljф, teknologi og samfund, pp. 203-218. Aalborg: Aalborg Universitetsforlag.

Licoppe, C. (2004). 'Connected' presence: The emergence of a new repertoire for managing social relationships in a changing communication technoscape. Environment and Planning D: Society and Space, 22, 135-156.

Ling, R. (2004). The mobile connection: The cell phone's impact on society. San Francisco: Elsevier Inc. \& Morgan Kaufmann Publishers.

Læssøe, J. (2001). Evaluering af Grøn Guide ordningen 1997 - 2000 (Evaluation of the Green Guide scheme 1997 - 2000). Copenhagen: Miljøstyrelsen.

Maag, J., \& Hansen, C. L. (2005). Collection potential for Nickel-Cadmium batteries in Denmark. Copenhagen: Danish Environmental Protection Agency.

Martens, S., \& Spaargaren, G. (2005). The politics of sustainable consumption: The case of the Netherlands. Sustainability: Science, Practice, \& Policy, 1(1).

http://ejournal.nbii.org/archives/vol1iss1/0410-009.martens.pdf

Mathios, A. M., \& Mayer, R. N. (2005). The changing relationship between consumer and environmental policy: Analyzing JCP's quarter century of coverage. In: K. G. Grunert \& J. Thøgersen (Eds.), Consumers, policy and the environment. A tribute to Folke Ölander, pp. 23-35. New York: Springer.

Ministry of Research (1994). Info-society 2000 - Report from the committee on the Information Society by the Year 2000. Copenhagen: Danish Ministry of Research. 
Ministry of Trade and Industry (1996). Erhvervsredeg 1996). Copenhagen: Danish Ministry of Trade and Industry.

Mol, A. P. J., \& Spaargaren, G. (2000). Ecological modernization in debate: A review.

Environmental Politics, 9 (1), 17-49.

NOAH-trafik (2003). Vedrørende debatoplaeg om Regionplan 2005 (Concerning the discussion paper on the regional plan 2005). URL (http://www.noah.dk/trafik/regionplan.htm) Access date 8-52006.

OECD (2002). Towards sustainable household consumption? Trends and policies in OECD countries. Paris: OECD Publications.

Olsen, A. M., Poulsen, H., Hansen, J. L., Andersen, P., \& Wiwe, P. (1980). Miljфkamp - erfaringer, kritik, visioner. En debatbog (The struggle on the environment - experience, criticism, visions. A discussion book). Copenhagen: NOAH's forlag.

Pedersen, I. L. (1999). Kommentar til debatoplag om transportsektorens $\mathrm{CO}_{2}$-udslip (Comments to the discussion paper on the $\mathrm{CO}_{2}$ emissions of the transport sector). URL (www.noah.dk/trafik/co2debat.html) Access date 8-5-2006.

Quitzau, M. (2004). Kultur i badeværelset - om integrationen af kultur, teknologi og samfund (Culture in the bathroom - about the integration of culture, technology, and society). Nordnytt, 90, 135-150.

Quitzau, M., \& Røpke, I. (forthcoming). The construction of normal expectations: The Danish bathroom boom. Submitted for review.

Rassing, C., \& Thulstrup, J. (2004). Danskerne...sådan ligger landet. Danskernes bekymringer, holdninger og adfærd fordelt på landsdele, på de nye regioner samt på køn og alder (The Danes ....as things are. The concerns, attitudes, and behaviour of Danes, distributed over parts of the country, the new regions, and over gender and age). Copenhagen: IFKA. 
Reisch, L. A. (2004). Sustainable consumption as a consumer policy issue. In: L. A. Reisch \& I. Røpke (Eds.), The ecological economics of consumption, pp. 175-189. Cheltenham, UK: Edward Elgar.

Remmen, A. (2002). Greening of Danish industry - Changes in concepts and policies. In: A. Jamison \& H. Rohracher (Eds.), Technology studies and sustainable development, pp. 171-198. Munich: Profil.

Remmen, A. (2006). Integrated product policy in Denmark. New patterns of environmental governance? In: D. Scheer \& F. Rubik (Eds.), Governance of integrated product policy. In search of sustainable production and consumption, pp. 103-125. Sheffield: Greenleaf Publishing.

Road Directorate (2004). Statistics on passenger traffic. URL (http://www.vejdirektoratet.dk/dokument.asp?page=document\&objno=79481) Access date 8-52006.

Rosa, H. (2003). Social acceleration: Ethical and political consequences of a desynchronized highspeed society. Constellations, 10 (1), 3-33.

Røpke, I. (1999). The dynamics of willingness to consume. Ecological Economics, 28 (3), 399-420.

Røpke, I. (2001a). Is consumption becoming less material? The case of services. International Journal of Sustainable Development, 4 (1), 33-47.

Røpke, I. (2001b). New technology in everyday life - social processes and environmental impact. Ecological Economics, 38 (3), 403-422.

Røpke, I. (2003). Consumption dynamics and technological change - exemplified by the mobile phone and related technologies. Ecological Economics, 45 (2), 171-188.

Sanches, S. (2005). Sustainable consumption à la française? Conventional, innovative, and alternative approaches to sustainability and consumption in France. Sustainability: Science, Practice, \& Policy, 1 (1). http://ejournal.nbii.org/archives/vol1iss1/0410-010.sanches.pdf

Schor, J. (2005). Prices and quantities: Unsustainable consumption and the global economy. Ecological Economics, 55 (3), 309-320. 
Shove, E. (2003a). Comfort, cleanliness and convenience. The social organization of normality. Oxford / New York: Berg.

Shove, E. (2003b). Converging conventions of comfort, cleanliness and convenience. Journal of Consumer Policy, 26 (4), 395-418.

Southerton, D. (2003). 'Squeezing time'. Allocating practices, coordinating networks and scheduling society. Time \& Society, 12 (1), 5-25.

Southerton, D., Chappells, H., \& Vliet, B. V., (Eds.) (2004). Sustainable consumption: The implications of changing infrastructures of provision. Cheltenham, UK: Edward Elgar.

StatBank Denmark (2005). Retrievals from the homepage of Statistics Denmark. Copenhagen: Statistics Denmark. URL (http://www.statistikbanken.dk) Access date 8-5-2006.

Statistics Denmark (2004). Informationssamfundet Danmark 2004 (The information society Denmark 2004). Copenhagen: Statistics Denmark.

Statistics Denmark (2005). Statistisk Årbog 2005 (Yearbook of statistics 2005). Copenhagen: Statistics Denmark.

Statistics Denmark \& Ministry of Research (2004). Informationssamfundet Danmark - IT-status 2004 (The information society Denmark - IT-status 2004). Copenhagen: Statistics Denmark \& Ministry of Research.

Thøgersen, J. (2005). How may consumer policy empower consumers for sustainable lifestyles? Journal of Consumer Policy, 28 (2), 143-178.

Thøgersen, J. \& Ölander, F. (2003). Spillover of environment-friendly consumer behaviour. Journal of Environmental Psychology, 23, 225-236.

Warde, A. (2005). Consumption and theories of practice. Journal of Consumer Culture, 5 (2), 131153.

Weale, A. (1992). The new politics of pollution. Manchester and New York: Manchester University Press. 
Wittchen, K. B. (2004). Vurdering af potentialet for varmebesparelser i eksisterende boliger (Assessment of the potential for heat-savings in existing dwellings). By og Byg Dokumentation 057. Hørshold: Statens Byggeforskningsinstitut.

Ölander, F., \& Thøgersen, J. (1995). Understanding of consumer behaviour as a prerequisite for environmental protection. Journal of Consumer Policy, 18 (4), 345-385. 